\title{
PENGARUH PENDAPATAN ASLI DAERAH, DANA ALOKASI UMUM, DAN DANA ALOKASI KHUSUS TERHADAP PENGALOKASIAN ANGGARAN BELANJA MODAL PADA KABUPATEN DAN KOTA DI PROVINSI JAWA TIMUR TAHUN 2013-2018
}

\author{
Ahmad Dalail ${ }^{1}$, Sukidin ${ }^{1}$, Wiwin Hartanto ${ }^{1}$ \\ ${ }^{1}$ Pendidikan Ekonomi, Fakultas Keguruan dan Ilmu Pendidikan, Universitas Jember \\ e-mail: ahmaddalail31097@gmail.com
}

\begin{abstract}
Abstrak
Otonomi daerah diharapkan meningkatkan kualitas pelayanan yang dilakukan oleh pemerintah untuk masyarakat, baik pelayanan yang sifatnya langsung maupun pelayanan yang tidak langsung, seperti pembangunan fasilitas umum dan fasilitas sosial lainnya, sehingga penyediaan barang publik dan pelayanan publik dapat lebih terjamin. Alokasi Belanja Modal dilandasi oleh kebutuhan daerah dari sarana dan prasarana, untuk pelaksanaan tugas pemerintahan maupun untuk fasilitas publik. Variabel yang berpengaruh terhadap pangalokasian Belanja Modal antara lain seperti Pendapatan Asli Daerah, Dana Alokasi Umum, dan Dana Alokasi Khusus. Oleh karena itu penelitian ini bertujuan untuk menguji pengaruh Pendapatan Asli Daerah (PAD), Dana Alokasi Umum (DAU) dan Dana Alokasi Khusus (DAK) terhadap Belanja Modal pada Pemerintah Kabupaten dan Kota di Jawa Timur tahun 2013-2018. Populasi pada penelitian ini adalah Kabupaten dan Kota di Provinsi Jawa Timur pada tahun 2013 sampai 2018. Penelitian ini menggunakan data sekunder dari dokumen Direktorat Jenderal Perimbangan Keuangan Kementerian Keuangan Republik Indonesia. Metode analisis data yang digunakan yaitu analisis regresi data panel dengan estimasi model Fixed Effect Model (FEM) dan bantuan program aplikasi EViews 9.0. Berdasarkan hasil penelitian menunjukkan bahwa Pendapatan Asli Daerah, Dana Alokasi Umum, dan Dana Alokasi Khusus secara bersama-sama (simultan) mempunyai pengaruh yang signifikan terhadap Belanja Modal di Provinsi Jawa Timur tahun 20132018. Besarnya pengaruh Pendapatan Asli Daerah, Dana Alokasi Umum, dan Dana Alokasi Khusus terhadap Belanja Modal di Provinsi Jawa Timur tahun 2013-2018 sebesar 90,2918\% sisanya sebesar 9,028\% dipengaruhi oleh variabel lain di luar penelitian ini. secara parsial 1) Pendapatan Asli Daerah berpengaruh positif terhadap pengalokasian Belanja Modal. 2) Dana Alokasi Umum berpengaruh positif terhadap pengalokasian Belanja Modal. 3) Dana Alokasi Khusus berpengaruh positif terhadap pengalokasian Belanja Modal.
\end{abstract}

Kata Kunci: Pendapatan Asli Daerah, Dana Alokasi Umum, Dana Alokasi Khusus, Belanja Modal.

\section{PENDAHULUAN}

Otonomi daerah pada dasarnya merupakan upaya pemberdayaan daerah untuk mengelola pembangunan di daerah dan mengelola APBD. Inovasi, kreativitas, dan kemandirian diharapkan akan dimiliki setiap daerah, sehingga dapat mengurangi tingkat ketergantungannya pada pemerintah pusat (Adisasmita 2011:83), selain itu dengan adanya otonomi daerah, diharapkan kualitas pelayanan yang dilakukan oleh pemerintah untuk masyarakat akan meningkat, baik pelayanan yang sifatnya langsung di berikan untuk masyarakat maupun pelayanan yang tidak langsung, seperti pembangunan fasilitas umum dan fasilitas sosial lainnya, sehingga penyediaan barang barang publik dan pelayanan publik dapat lebih terjamin.

Berdasarkan karakteristiknya, Belanja dikelompokkan menjadi Belanja Operasi, Belanja Modal, dan Belanja Tak Terduga. Belanja pemerintah daerah yang ada dalam APBD adalah kegiatan rutin pengeluaran kas daerah untuk membiayai kegiatan-kegiatan operasi dalam pemerintahan. Belanja yang semakin meningkat menyebabkan dana yang di butuhkan besar juga, dengan terpenuhinya kebutuhan belanja pemerintah, maka diharapkan pelayanan terhadap masyarakat menjadi lebih baik dan kesejahteraan masyarakat menjadi meningkat. Belanja daerah dapat menjadi pedoman tolak ukur keberhasilan pelaksanaan kewenangan daerah, sehingga pengalokasian dana belanja daerah harus dilakukan secara efektif dan efisien. Pemerintah daerah mengeluarkan dana dalam bentuk anggaran Belanja Modal 
pada APBD untuk menambah aset tetap dan aset lainnya yang memberi manfaat lebih dari satu periode akuntansi.

Alokasi Belanja Modal dilandasi akan kebutuhan daerah dari sarana dan prasarana, baik untuk pelaksanaan tugas pemerintahan maupun untuk fasilitas publik, karena itu dalam upaya meningkatkan kualitas pelayanan publik, pemerintah daerah diharapkan mengubah komposisi belanjanya menjadi lebih efektif dan efisien. Pemanfaatan belanja seharusnya dialokasikan untuk hal-hal produktif, misal untuk melakukan aktivitas pembangunan (Saragih, 2003:121). Sejalan dengan pendapat tersebut, Stine (dalam Jemparut dan Riduwan, 2017) menyatakan bahwa penerimaan pemerintah sebaiknya lebih banyak untuk program-program layanan publik. Kedua pendapat ini mengartikan pentingnya mengalokasikan belanja untuk berbagai kepentingan publik atau Belanja Modal, agar bisa meningkatkan pengalokasian Belanja Modal, perlu diketahui variabel-variabel yang berpengaruh terhadap pangalokasian Belanja Modal, seperti Pendapatan Asli Daerah, Dana Alokasi Umum, dan Dana Alokasi Khusus.

Alokasi proporsi belanja daerah pada Provinsi Jawa Timur saat ini memang menjadi fokus utama, hal ini dapat dilihat dari data laporan APBD yang dapat diakses pada website Direktoral Jenderal Perimbangan Keuangan yang menyatakan "APBN merupakan instrumen kebijakan penting untuk mencapai tujuan nasional dan pelaksanaan program Nawacita. Pemerintah terus berkomitmen menjaga pengelolaan fiskal yang sehat dan berkelanjutan, dengan fokus prioritas pembangunan nasional pada 2018, yaitu: (1) pembangunan infrastruktur; (2) pengurangan kemiskinan serta kesenjangan antar-pendapatan dan antar wilayah; serta (3) perluasan kesempatan kerja".

Berdasarkan uraian diatas dapat dirumuskan masalah sebagai berikut: 1) Apakah Pendapatan Asli Daerah, Dana Alokasi Umum, Dana Alokasi khusus berpengaruh terhadap Belanja Modal?, 2) Apakah secara parsial Pendapatan Asli Daerah, Dana Alokasi Umum, Dana Alokasi khusus berpengaruh terhadap Belanja Modal?

\section{METODE}

Penelitian ini merupakan penelitian kuantitatif dengan metode eksplanatory yaitu menjelaskan variabel bebas terhadap variabel terikat, serta pengaruh antara dua variabel bebas atau lebih terhadap variabel terikat melalui pengujian. Penelitian ini menggunakan data panel (pooled data) yaitu penggabungan antara data time series (runtun waktu) yaitu dari tahun 2013-2018 dan cross section (data silang) yaitu data Kabupaten/Kota di Provinsi Jawa Timur. Penelitian ini menggunakan analisis regresi data panel melalui program Eviews 9 sebagai pengolah data. "Data panel (pooled data) adalah sebuah set data yang berisi data sampel individu (rumah tangga, perusahaan, Kabupaten/Kota, dll) pada periode waktu tertentu" (Ekananda, 2015). Data panel (pooled data) merupakan penggabungan data time series dan cross section.

Analisis ini digunakan untuk menguji pengaruh Pendapatan Asli Daerah, Dana Alokasi Umum, dan Dana Alokasi Khusus terhadap Belanja Modal pada Kabupaten/Kota di Provinsi Jawa Timur. Sebelum melakukan analisis regresi berganda terlebih dahulu datanya di uji dalam uji asumsi klasik yang bertujuan untuk memastikan bahwa data yang diperoleh memenuhi syarat yang telah ditentukan. Setelah persyaratan regresi dari uji asumsi klasik telah terpenuhi maka pengujian regresi dapat dilakukan.

\section{HASIL DAN PEMBAHASAN HASIL PENELITIAN}

\section{Uji Asumsi Klasik}

Uji asumsi klasik yang pertama yaitu uji Multikolinieritas untuk mengetahui apakah model regresi ditemukan adanya korelasi antar dua (atau lebih) Data yang baik apabila nilai korelasi antar variabel independen di bawah 0,8 (Gujarati, 2006:68). Berdasarkan hasil uji menunjukkan koefisien korelasi variabel independen kurang dari 0,8. Maka, dapat disimpulkan bahwa data tersebut tidak terjadi multikolinieritas.

Uji asumsi klasik selanjutnya yaitu uji heteroskedastisitas. Pengujian ini dilakukan untuk mengetahui model regresi terjadi ketidaksamaan varians dari residual satu pengamatan ke pengamatan yang lain. Metode yang digunakan untuk mendeteksi heteroskedastisitas, salah satunya dengan 
melakukan Uji Glejser (Gujarati, 2006:93). Apabila nilai t-statistik $>$ t-tabel atau nilai prob $<\alpha=5 \%$, maka ada heteroskedastisitas. Sebaliknya, jika t-statistik $<\mathrm{t}$-tabel atau nilai prob $>\alpha=5 \%$, maka tidak ada heteroskedastisitas. Berdasarkan hasil pengujian menunjukkan bahwa nilai probabilitas masingmasing variabel independen berada di atas $\alpha(5 \%)$, sehingga data dalam penelitian ini dikatakan homoskedastisitas dan terbebas dari masalah heteroskedastisitas.

Estimasi Model Regresi

Pemilihan model yang tepat dalam pengujian dilakukan dengan uji hausman. Uji hausman digunkan untuk memilih model yang tepat di antara Fixed Effect Model (FEM) dan Random Effect Model (REM). Hasil pengujian dengan uji Hausman membuktikan bahwa estimasi model dalam penelitian ini yang terbaik adalah dengan menggunakan Fixed Effect Model (FEM).

Analisis Regresi Data Panel

Analisis untuk mengetahui pengaruh Pendapatan Asli Daerah, Dana Alokasi Umum, dan Dana Alokasi Khusus terhadap Belanja Modal di Provinsi Jawa Timur tahun 2013-2018, dilakukan dengan analisis data panel dengan model yang terpilih, yaitu Fixed Effect Model (FEM).

Berikut hasil regresi dengan Fixed Effect Model (FEM)

Tabel 1 Hasil Regresi Data Panel dengan Fixed Effect Model (FEM)

\begin{tabular}{ccccc}
\hline Variable & Coefficient & Std. Error & t-Statistic & Prob. \\
\hline C & -266741.5 & 77757.49 & -3.430429 & 0.0007 \\
PAD & 0.937095 & 0.064521 & 14.52382 & 0.0000 \\
DAU & 0.307210 & 0.090171 & 3.406968 & 0.0008 \\
DAK & 0.137066 & 0.072796 & 1.882882 & 0.0613 \\
\hline
\end{tabular}

Sumber: Data diolah (2019)

Berdasarkan tabel 4.8 menunjukkan bahwa Pendapatan Asli Daerah, Dana Alokasi Umum, dan

Dana Alokasi Khusus berpengaruh terhadap Belanja Modal di Provinsi Jawa Timur tahun 2013-2018, diperoleh persamaan sebagai berikut:

$\mathrm{BM}=-266741.5+0.937095 * \mathrm{PAD}+0.307210 * \mathrm{DAU}+0.137066 * \mathrm{DAU}$

Berdasarkan hasil regresi pada tabel 1 dapat dijelaskan sebagai berikut.

1) Variabel Pendapatan Asli Daerah berpengaruh signifikan dan positif terhadap Belanja Modal di Provinsi Jawa Timur tahun 2013-2018. Nilai koefisien yaitu 0,937095. Artinya, apabila di Provinsi Jawa Timur terjadi kenaikan PAD sebesar 1 juta, maka Belanja Modal akan naik sebesar 0,937095 juta dengan asumsi variabel bebas yang lain, yaitu DAU dan DAK tetap (ceteris paribus). Hasil regresi dalam penelitian ini sesuai dengan teori yang mengatakan bahwa kenaikan PAD akan meningkatkan Belanja Modal.

2) Variabel Dana Alokasi Umum berpengaruh signifikan dan positif terhadap Belanja Modal di Provinsi Jawa Timur tahun 2013-2018. Nilai koefisien yaitu 0,307210. Artinya, apabila di Provinsi Jawa Timur terjadi kenaikan Dana Alokasi Umum sebesar 1 juta, maka Belanja Modal akan meningkat sebesar 0,307210 juta dengan asumsi variabel bebas yang lain, yaitu PAD dan DAK tetap (ceteris paribus). Hasil regresi dalam penelitian ini sesuai dengan teori yang mengatakan bahwa kenaikan DAU akan meningkatkan Belanja Modal.

3) Variabel Dana Alokasi Khusus berpengaruh positif terhadap Belanja Modal di Provinsi Jawa Timur tahun 2013-2018. Nilai koefisien yaitu 0,137066. Artinya, apabila di Provinsi Jawa Timur terjadi kenaikan Dana Alokasi Khusus sebesar 1 juta, maka Belanja Modal akan meningkat sebesar 0,137066 juta dengan asumsi variabel bebas yang lain, yaitu PAD dan DAU tetap (ceteris paribus). Hasil regresi dalam penelitian ini sesuai dengan teori yang mengatakan bahwa kenaikan DAK akan meningkatkan Belanja Modal.

4) Apabila variabel Pendapatan Asli Daerah, Dana Alokasi Umum, dan Dana Alokasi Khusus bernilai 0, maka Belanja Modal akan menurun sebesar 266741.5 juta.

Uji Signifikansi Statistik

1) Uji F (simultan) dilakukan untuk mengetahui besarnya pengaruh variabel bebas terhadap variabel terikat secara bersama. Pengaruh PAD, DAU, dan DAK terhadap Belanja modal di Provinsi Jawa 
Timur tahun 2013-2018 secara simultan dapat dilihat pada tabel berikut dengan nilai signifikansi 0,05 .

Tabel 2 Hasil Uji F

\begin{tabular}{llll} 
R-squared & 0.920025 & Mean dependent var & 383885.7 \\
$\begin{array}{l}\text { Adjusted } \\
\text { squared }\end{array}$ & 0.902918 & S.D. dependent var & 326314.7 \\
S.E. of regression & 101673.0 & Akaike info criterion & 26.05832 \\
Sum squared resid & $1.93 \mathrm{E}+12$ & Schwarz criterion & 26.67500 \\
Log likelihood & -2929.649 & Hannan-Quinn criter. & 26.30714 \\
F-statistic & 53.78086 & Durbin-Watson stat & 1.910740 \\
Prob(F-statistic) & $\mathbf{0 . 0 0 0 0 0 0}$ & & \\
\hline
\end{tabular}

Sumber: Data Diolah (2019)

Berdasarkan hasil di atas menunjukkan bahwa nilai Prob (F-statistic) sebesar 0,000000 < 0,05, sehingga dapat disimpulkan bahwa Pendapatan Asli Daerah, Dana Alokasi Umum, dan Dana Alokasi Khusus secara bersama-sama (simultan) mempunyai pengaruh yang signifikan terhadap Belanja Modal di Provinsi Jawa Timur tahun 2013-2018.

2) Uji t (parsial) dilakukan untuk mengetahui besarnya pengaruh variabel bebas terhadap variabel terikat secara satu per satu.

Tabel 3 Hasil Uji t

\begin{tabular}{llcll}
\hline Variabel & t-hitung & t-tabel $(\alpha=5 \%)$ & Probabilitas & Keterangan \\
\hline PAD & 14.52382 & 1.651685 & 0.0000 & Signifikan positif \\
DAU & 3.406968 & 1.651685 & 0.0008 & Signifikan positif \\
DAk & 1.882882 & 1.651685 & 0.0613 & Signifikan positif \\
\hline
\end{tabular}

Sumber : Data Diolah (2019)

Berdasarkan tabel 4.9 menunjukkan pengaruh Pengaruh PAD, DAU, dan DAK terhadap Belanja Modal di Provinsi Jawa Timur tahun 2013-2018 secara parsial dengan keterangan sebagai berikut:

a) Nilai variabel PAD t-hitung lebih besar daripada t tabel yaitu 14,52382 lebih besar daripada 1,651685 , sehingga dapat disimpulkan bahwa ada pengaruh signifikan positif PAD terhadap Belanja Modal di Provinsi Jawa Timur.

b) Nilai variabel DAU t-hitung lebih besar daripada t tabel yaitu 3,406968 lebih besar dari pada 1,651685 , sehingga dapat disimpulkan bahwa ada pengaruh signifikan positif antara DAU terhadap Belanja Modal di Provinsi Jawa Timur.

c) Nilai variabel DAK t-hitung lebih besar daripada t tabel yaitu 1,882882 lebih besar daripada 1,651685 , sehingga dapat disimpulkan bahwa ada pengaruh signifikan positif antara DAK terhadap Belanja Modal di Provinsi Jawa Timur

d) Berdasarkan hasil uji t menunjukkan bahwa ada pengaruh parsial variabel bebas terhadap Belanja Modal di Provinsi Jawa Timur tahun 2013-2018 sehingga $\mathrm{H}_{1}$ diterima dan $\mathrm{H}_{0}$ ditolak..

3) Determinasi $R^{2}$ digunakan untuk mengetahui seberapa besarnya variabel bebas dapat menerangkan variabel terikat (dependen). Semakin tinggi nilainya atau mendekati angka 1, maka semakin tinggi suatu model menjelaskan variabel dependennya. Demikian juga sebaliknya, semakin kecil dan mendekati angka 0 , maka semakin rendah suatu model menjelaskan variabel dependennya. Berikut hasil determinasi $\mathrm{R}^{2}$

Tabel 4 Determinasi $\mathrm{R}^{2}$

\begin{tabular}{llll}
\hline R-squared & $\mathbf{0 . 9 2 0 0 2 5}$ & Mean dependent var & 383885.7 \\
Adjusted R-squared & $\mathbf{0 . 9 0 2 9 1 8}$ & S.D. dependent var & 326314.7 \\
S.E. of regression & 101673.0 & Akaike info criterion & 26.05832 \\
Sum squared resid & $1.93 \mathrm{E}+12$ & Schwarz criterion & 26.67500 \\
Log likelihood & -2929.649 & Hannan-Quinn criter. & 26.30714 \\
F-statistic & 53.78086 & Durbin-Watson stat & 1.910740
\end{tabular}


Prob(F-statistic) $\quad 0.000000$

Sumber: Data Diolah (2019)

Hasil determinasi koefisien $\left(\mathrm{R}^{2}\right)$ menunjukkan Pendapatan Asli Daerah, Dana Alokasi Umum, dan Dana Alokasi Khusus berpengaruh terhadap Belanja Modal di Provinsi Jawa Timur tahun 2013-2018 sebesar 0,920025, hal ini menunjukkan bahwa variabel bebas sangat kuat dalam menjelaskan variabel terikat. Besarnya pengaruh variabel resonse dengan memperhatikan standar error dapat dilihat dari hasil Adjusted R-squared yakni sebesar 0,902918 berarti sebanyak 90,2918\% Belanja Modal dipengaruhi oleh Pendapatan Asli Daerah, Dana Alokasi Umum, dan Dana Alokasi Khusus di Provinsi Jawa Timur, sedangkan sisanya yaitu sebanyak 9,7082\% dipengaruhi oleh variabel lain yang tidak ada dalam penelitian.

\section{PEMBAHASAN}

Penelitian ini dilakukan untuk mengetahui pengaruh Pendapatan Asli Daerah, Dana Alokasi Umum, dan Dana Alokasi Khusus terhadap Belanja Modal di Provinsi Jawa Timur tahun 2013-2018. Pendapatan Asli Daerah berpengaruh signifikan dan positif terhadap Belanja Modal di Provinsi Jawa Timur tahun 2013-2018. Pendapatan Asli Daerah berpengaruh positif terhadap Belanja Modal dikarenakan Pendapatan Asli Daerah adalah sumber pembiayaan pemerintahan daerah dalam mengembangkan pembangunan daerah. Pendapatan Asli Daerah bersumber dari hasil pajak daerah, hasil retribusi daerah, hasil pengelolaan kekayaan daerah yang dipisahkan dan lain-lain PAD yang sah (Halim \& Kusufi, 2013). Daerah yang didukung dengan sarana dan prasarana yang memadai akan berpengaruh pada tingkat produktivitas masyarakat dan pada akhirnya akan meningkatkan Pendapatan Asli Daerah, dengan demikian pemerintah daerah akan berinisiatif agar dapat lebih menggali potensi Pendapatan Asli Daerah yang dimiliki termasuk salah satunya dengan cara meningkatkan pembangunan infrastuktur sehingga berdampak pada peningkatan pertumbuhan ekonomi daerah tersebut. Hasil penelitian ini sejalan dengan hasil penelitian yang dilakukan oleh Al Azhar dan Hermanto (2017) yang menyatakan bahwa Pendapatan Asli Daerah berpengaruh positif dan signifikan terhadap Belanja Modal.

Dari hasil analisis dapat disimpulkan bahwa ada pengaruh signifikan positif PAD terhadap Belanja Modal di Provinsi Jawa Timur. Hal tersebut sejalan dengan hasil penelitian yang dilakukan oleh Al Azhar dam Hermanto (2017), Kusnandar dan Dodik Siswanto, Susilawati dan Riharjo (2014) maupun Jemparut dan Ridwan (2017) yang menghasilkan bahwa Pendapatan Asli Daerah memiliki pengaruh positif dan signifikan terhadap Belanja Modal. Melihat hasil penelitian diatas telah menunjukan bahwa Pendapatan Asli Daerah merupakan sumber pendapatan penting bagi sebuah daerah dalam memenuhi belanjanya.

Daerah diharapkan dapat lebih mengoptimalkan penerimaan daerah, oleh karena itu pemerintah daerah hendaknya lebih mengoptimalkan pemanfaatan sumber daya daerah untuk dapat digunakan dalam rangka kegiatan yang dapat meningkatkan pendapatan. Peningkatan alokasi Belanja Modal dalam bentuk aset tetap seperti infrastruktur dan peralatan merupakan hal yang sangat penting untuk meningkatkan produktivitas perekonomian karena semakin tinggi Belanja Modal semakin tinggi pula produktivitas perekonomian, dan peningkatan produktivitas perekonomian tersebut akan memberi dampak positif pada peningkatan pendapatan daerah tersebut.

Pada 38 Kabupaten/Kota di Jawa Timur Kabupaten Malang memperoleh Dana Alokasi Umum (DAU) terbesar di Jawa Timur pada tahun 2013-2015, untuk tahun 2016-2018 diperoleh oleh Kabupaten Jember. Tingginya Dana Alokasi Umum disebabkan oleh celah fiskal yang terjadi karena kebutuhan fiskal daerah melebihi kemampuan fiskal sehingga Pemerintah Daerah membutuhkan bantuan lain berupa Dana Alokasi Umum. Pemerintah Daerah dapat meminimalisir celah fiskal tersebut jika Pemerintah Derah dapat meningkatkan kemampuan fiskalnya, salah satunya melalui peningkatan Pendapatan Asli Daerah.

Dari hasil analisis dapat disimpulkan bahwa ada pengaruh signifikan positif antara DAU terhadap Belanja Modal di Provinsi Jawa Timur tahun 2013-2018. Hal ini mengindikasikan bahwa Dana Alokasi Umum yang selama ini diterima daerah digunakan untuk pembangunan daerah yang terdapat dalam alokasi Belanja Modal. Dana Alokasi Umum bersifat "Block Grant", memungkinkan daerah menggunakan sesuai dengan prioritas dan kebutuhan daerah untuk peningkatan pelayanan kepada 
masyarakat dalam rangka otonomi daerah (Halim \& Kusufi, 2013). Dari olah data dan hasil yang diperoleh mengindikasikan bahwa Dana Alokasi Umum yang diterima oleh daerah tidak hanya diperuntukan untuk membiayai pengeluaran rutin, seperti untuk belanja pegawai dan digunakan untuk Belanja Modal. Alasan Dana Alokasi Umum berpengaruh positif terhadap Belanja Modal adalah karena tujuan dari Dana Alokasi Umum merupakan untuk menyediakan dana yang cukup bagi pemerintah daerah dalam menjalankan kegiatan daerahnya. Diberikannya bantuan Dana Alokasi Umum ini karena tidak meratanya kemampuan keuangan antar daerah, bagi pemerintah daerah yang memiliki Pendapatan Asli Daerah yang kecil, Dana Alokasi Umum sangat berperan penting bagi pemerintah daerah untuk menambah aset tetap dan aset lainnya yang dapat meningkatkan pembangunan daerahnya. Hasil penelitian ini sejalan dengan hasil penelitian yang dilakukan oleh Purpitasari (2015) dalam penelitiannya tentang Pengaruh Pendapatan Asli Daerah Dan Dana Alokasi Umum Terhadap Alokasi Belanja Daerah yang menyatakan bahwa Dana Alokasi Umum berpengaruh positif dan signifikan terhadap Belanja Daerah.

Pada 38 Kabupaten/Kota di Jawa Timur Dana Alokasi Khusus terbesar di Jawa Timur pada tahun 2013 diperoleh oleh Kabupaten Malang, Kabupaten Pasuruan pada tahun 2014, Kab Bangkalan pada tahun 2015, Kab Tulungagung pada tahun 2016, dan Kab Malang pada tahun 2017-2018. Dana Alokasi Khusus dialokasikan kepada daerah tertentu dengan tujuan membantu mendanai kegiatan khusus yang merupakan urusan daerah dan sesuai dengan prioritas nasional (UU No. 33 Tahun 2004).

Dari hasil analisis statistik dapat disimpulkan bahwa ada pengaruh signifikan positif antara Dana Alokasi Khusus (DAK) terhadap Belanja Modal di Provinsi Jawa Timur tahun 2013-2018. Dana Alokasi Khusus berpengaruh positif terhadap Belanja Modal karena Pemanfaatan Dana Alokasi Khusus salah satunya diarahkan pada kegiatan investasi pembangunan, pengadaan, peningkatan, dan perbaikan sarana dan prasarana fisik dengan umur ekonomis yang panjang, termasuk pengadaan sarana fisik penunjang (Adisasmita, 2011). Pengalokasian Dana Alokasi Khusus diharapkan dapat mempengaruhi pengalokasian anggaran Belanja Modal, karena Dana Alokasi Khusus cenderung akan menambah aset tetap yang dimiliki pemerintah guna meningkatkan pelayanan publik. Hasil penelitian ini sejalan dengan hasil penelitian yang dilakukan oleh Al Azhar dam Hermanto (2017) yang melakukan penelitian tentang Pengaruh Pendapatan Asli Daerah, Dana Alokasi Umum, dan Dana Alokasi Khusus Terhadap Belanja Modal yang menyatakan Bahwa Dana Alokasi Khusus berpengaruh signifikan positif terhadap Belanja Modal. Berdasarkan hasil penelitian menunjukkan bahwa nilai Prob (F-statistic) sebesar $0,000000<0,05$. H0 ditolak dan H1 diterima, sehingga dapat disimpulkan bahwa Pendapatan Asli Daerah, Dana Alokasi Umum, dan Dana Alokasi Khusus secara bersama-sama (simultan) mempunyai pengaruh yang signifikan terhadap Belanja Modal di Provinsi Jawa Timur tahun 2013-2018. Hal tersebut sejalan dengan hasil penelitian yang dilakukan oleh Al Azhar dam Hermanto (2017)

\section{PENUTUP}

Berdasarkan hasil dan pembahasan penelitian yang telah dilakukan mengenai pengaruh Pendapatan Asli Daerah pengaruh Pendapatan Asli Daerah, Dana Alokasi Umum, dan Dana Alokasi Khusus terhadap Belanja Modal di Provinsi Jawa Timur tahun 2013-2018 dapat disimpulkan bahwa secara simultan ketiga variabel independen yaitu Pendapatan Asli Daerah, Dana Alokasi Umum dan Dana Alokasi Khusus berpengaruh positif terhadap variabel dependen (Belanja Modal) dan secara parsial, masingmasing variabel Pendapatan Asli Daerah, Dana Alokasi Umum, dan Dana Alokasi Khusus dapat disimpulkan sebagai berikut: 1) Pendapatan Asli Daerah berpengaruh positif terhadap Belanja Modal Yang artinya apabila semakin tinggi Pendapatan Asli Daerah yang diterima oleh suatu daerah maka semakin tinggi pula Belanja Modal yang akan di alokasikan oleh daerah tersebut; 2) Dana Alokasi Umum berpengaruh positif terhadap Belanja Modal. Yang artinya semakin tinggi Dana Alokasi Umum yang diterima oleh suatu daerah maka semakin besar pula Belanja Modal yang dapat di alokasikan oleh daerah tersebut; 3) Dana Alokasi Khusus berpengaruh positif terhadap Belanja Modal. Yang artinya semakin tinggi Dana Alokasi Khusus yang diterima oleh suatu daerah maka semakin besar pula Belanja Modal yang dapat di alokasikan oleh daerah tersebut.

\section{DAFTAR PUSTAKA}


Adisasmita, R. (2011). Pembiayaan Pembangunan Daerah. Yogyakarta: GRAHA ILMU.

Al Azhar, A., \& Hermanto, S. B. (2017). PENGARUH PENDAPATAN ASLI DAERAH, DANA ALOKASI UMUM DAN DANA ALOKASI KHUSUS TERHADAP BELANJA MODAL. Jurnal Ilmu dan Riset Akuntansi, 6.

Ekananda, M. (2015). Ekonometrika Dasar Untuk Penelitian Ekonomi, Sosial dan Bisnis. Jakarta: Mitra Wacana Media.

Gujarati, D. N. (2006). Dasar-dasar Ekonometrika Jilid 2. Jakarta: Erlangga.

Halim, A., \& Kusufi, M. S. (2013). Akuntansi Sektor Publik, Akuntansi Keuangan Daerah. Jakarta: Salemba Empat.

Jemparut, M. S., \& Riduwan, A. (2017). PENGARUH PENDAPATAN ASLI DAERAH DAN DANA ALOKASI UMUM PADA BELANJA MODAL. Jurnal Ilmu dan Riset Akuntansi, 6. Purpitasari, P., \& Kurnia. (2015). PENGARUH PENDAPATAN ASLI DAERAH DAN DANA ALOKASI UMUM TERHADAP ALOKASI BELANJA DAERAH. Jurnal Ilmu \& Riset Akuntansi, 4.

Ratmono, D., \& Sholihin, M. (2015). Akuntansi Keuangan Daerah Basis Akrual. Yogyakarta: UPP STIM YKPN.

Saragih, J. P. (2003). Desentralisasi Fiskal dan Keuangan Daerah dalam Otonomi. Jakarta: Ghalia Indonesia.

Siswantoro, D., \& Kusnandar. (n.d.). PENGARUH DANA ALOKASI UMUM, PENDAPATAN ASLI DAERAH, SISA LEBIH PEMBIAYAAN ANGGARAN DAN LUAS WILAYAH TERHADAP BELANJA MODAL.

Sun'an, M., \& Senuk, A. (2015). Ekonomi Pembangunan Daerah. Jakarta: Mitra Wacana Media. Susilawati, E., \& Riharjo, I. B. (2014). PENGARUH PENDAPATAN ASLI DAERAH DAN DANA ALOKASI UMUM TERHADAP ALOKASI BELANJA DAERAH. Jurnal Ilmu \& Riset Manajemen, 3. 